\title{
獣害対策における都道府県の実施体制と市町村との関係 \\ 一近业地方における野生鳥獣被害対策を事例に一 \\ The Relationship between Implementation System of Wildlife Management in Prefectures and its Cooperation with Municipalities
}

-A Case Study of Prefectures in Kinki Area-

\author{
岸岡智也* 橋本 禅** 星野 敏** 九鬼康彰** \\ Tomoya KISHIOKA*, Shizuka HASHIMOTO** , Satoshi HOSHINO** and Yasuaki KUKI** \\ (*京都大学大学院農学研究科 **京都大学大学院地球環境学堂) \\ (*Graduate School of Agriculture Kyoto University ${ }^{* *}$ Graduate School of Global Environmental Studies, Kyoto University)
}

\section{I はじめに}

野生動物による農林業被害の拡大が問題となっている 中, 獣害対策における国や都道付県, 市町村の役割は徐々 に変化している。1999 年に「鳥獣の保護及び狩編の適正 化に関する法律（以下，鳥獣保護法)」が改正され，特定 鳥獣保護管理計画制度が導入された。これにより都道府県 は,これまでの鳥獣保護事業計画に加え，行政区域内で「そ の数が著しく増加又は減少している鳥獣」について，特定 鳥獣保護管理計画（以下，特定計画）により，数值目標を 伴った保護管理を図ることが可能になった(同法第 7 条)。 2008 年には，農山漁村で増加する鳥獣害に対処すべく， 「鳥獣による農林水産業等に係る被害の防止のための特 別措置に関する法律（以下，特措法)」が制定された。こ れにより市町村は，加害鳥獣に対して被害防止計画を定め られるほか(同法第 4 条 2 項)，これまで鳥獣保護法に基 づき都道府県知事が実施してきた捕獲等の許可を，対象と した鳥獣に限り市町村長の権限で実施できることになっ た（同法第 4 条 7 項）。また，2012 年の同法の改正では, 市町村の権限や国および都道府県の財政支援のさらなる 拡充が図られた注1)。

このように,これまで都道府県が主導してきた獣害対策 は，特措法の制定，改正により，被害発生地により近い市 町村において積極的に推進できるようになった ${ }^{1) 。 た た ゙ し ， ~}$ 特措法は市町村の被害防止計画作成に際し，都道府県の鳥 獣保護事業計画や特定計画との整合性の確保を求めてい る（同法第 4 条 7 項)。また都道府県は，対策技術の開発 や普及，特定計画による個体数等の目標設定，国や市町村 との調整や被害防止計画を持たない市町村での捕獲の許 可など，㑈然として重要な役割を担っている。獣害対策の 円滑かつ効果的な遂行には，都道府県と市町村の意思踈通 や調整がこれまで以上に求められる。

\section{II 研究の目的}

鳥獣保護法や特措法の業務を所掌する都道倠県では， 被害軽減だけでなく，野生動物保護の観点からも業務を 遂行する必要がある。そのため，都道府県における業務 には，農業部局や環境部局，林務部局などの複数の部局 が関わることとなる。獣害対策の業務を円滑に進めるた めには部局間の連携が不可欠である。しかし，これまで の研究では, 都道府県レベルでの部局間連携の体制や, 各体制が持つ，国や市町村との調整を含めた業務遂行上 の利点や課題等の把握はほとんど行われてこなかった。

本研究は，都道府県における獣害対策行政に関わる部 局間の連携や役割分担，市町村との連絡調整について， 各体制の特徽や課題を横断的に明らかにすることを目的 とする。これにより，行政担当者がこれまで業務を実際 に行うなかでしか認識されてこなかった課題を行政担当 者だけでなく，獣害対策に関わる多くの関係者が広く共 有，認識するべき問題として提起する。それと共に，国 や市町村など他の対策実施主体との連携の中で都道府県 が果たすべき機能とそのために効果的な対策実施体制の 構築に資する知見を得たい。

本研究では近畿地方の 6 府県を事例とした。近畿地方 では以前から, 農業被害が特に樑刻なニホンジカ, 二木 ンザル，イノシシのすべてで広範围に被害が発生して打 り，その取り組みも早くから行われており，さまざまな 部局間連携が図られていると考えられる。

III 研究の方法

\section{1 分析の枠組み}

（1）実施体制の捉え方

獣害対策には被害防除，個体数管理，生息地管理が求 


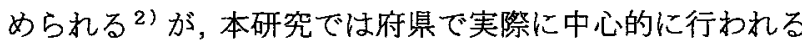
被害防除と個体数管理の 2 つの対策業務で主となる(1)鳥 獣保護法におおる計画策定，(2)狩猟管理（有害鳥獣捕獲を 含む)，(3)特措法の所管，(4)被害防除の 4 業務に注目する。 これら業務を複数の部局が分担しているか，もしくは 1 部 局が全業務を所掌しているかで，府県の獣害対策の実施の スタイルは異なる。対象とした業務は，対象 6 府県のすべ てで梁刻な農作物被害のあるイノシシ，ニホンジカ，二ホ ンザルの被害対策である。本研究では，近畿 6 府県の獣害 対策業務を所掌する部局の担当者に対するヒアリング調 查により，近畿地方の地方自治体における獣害対策につい て，各部局の業務内容や役割分担の状況により，対策の実 施体制を捉える。

\section{（2）実施体制の類型化}

農業被害が拡大する野生動物被害の問題において，実際 の被害地である農業地域との関係や知識を持つ農業部局 の役割は不可欠である。対策への農業部局への関わり方が 府県の対策実施体制を特徽づけると考えられる。本稿では， 被害防除と個体数管理の業務を担当する部局の数, 農業部 局の担当業務，の 2 つの観点から，6 府県の獣害対策の実 施体制を，(1)被害防除と個体数管理を異なる部局が分担す る府県，(2)被害防除と個体数管理を農業部局が専管する府 県，(3)被害防除と個体数管理を農業部局以外の部局が専管 する府県，の3つに類型化し，それぞれの体制の特徵を整 理する。

\section{（3）市町村からみた都道府県の体制の評価}

次に，類型化した府県の体制ごとに市町村を選定し，被 害対策担当者へのヒアリング調查を行った。ここから，府 県の体制の類型ごとの特徵と課題, さらに市町村との連携 の面から見た特徵と課題の把握を試みた。

\section{2 調查の方法}

（1）府県担当者へのヒアリング調査

本研究では, 2011 年 10 月から 2012 年 2 月にか和和歌 山県（農林水産部農業生産局 果樹園芸課 農業環境・鳥獣 害対策室，および環境生活部環境政策局 環境政策総務課 自然環境室)，滋賀県 (琵琶湖環境部 自然環境保全課 野 生生物担当, および農政水産部 農業経営課 水田農業・獣 害対策担当), 兵庫県（農政環境部環境創造局 自然環境課 野生鳥獣係)，奈良县(農林部森林整備課 鳥獣保護倸)， 京都府（農林水産部 森林保全課 野生鳥獣担当），大阪府 （環境農林水産部 動物愛護畜産課 野生動物グループ）の 関係部局の行政担当者を対象としたヒアリング調查を実 施した。ヒアリングでは，獣害対策に関わる部局，各部局 の所管業務や権限などの役割分担による獣害対策の実施 体制の現状, 市町村への権限の委譲の状況, 体制変化の状 況及び経緯, 市町村や被害発生地住民との連絡調整の体制
について把握した。

（2）市町村担当者へのヒアリング調查

府県の獣害対策実施体制の類型結果にもとづき，各類 型に対応する市町村を次の基淮に照らして各一つ選び， 行政担当者へのヒアリング調查を実施した。選定基準は， (1)府県の策定する特定計画の対象種による被害が発生し ていること，(2)被害の状況や対策の実施内容が府県下で 一般的であること，(3)特措法に基づく被害防止計画を策 定していること，(4)同一の担当者が数年在籍し，被害防 止計画の策定過程や事業の詳細を把握していることの 4 点である。

選定したのは，滋賀県甲賀市（産業経済部鳥獣害対策 室)，和歌山県紀美野町（産業課），京都府南丹市（農林 商工部農林整備課）の行政担当者である。ヒアリングで は，被害防止計画における府県との調整の状況，特措法 制定による権限や財政支援の変化，業務や計画の調整に おける都道府県との関係について把握した。

IV 結果

\section{1 各府県の体制}

（1）各府県の担当部局

獣害対策の担当部局は，大きく「環境部局」「農業部局」 「林務部局」に分けられた（図 1)。京都府を除き，20 の部局にわたり業務が分担されていた。各府県の担当部 局の特徵は次のとおりである。

和歌山県 環境部局と農業部局で役割が分担されていた。 2011 年度より農業部局に獣害対策専門に業務を行う「果 樹園芸課 農業環境・鳥獣害対策室」が設置された（図 1 )。 農業部局は特措法が制定された 2008 年度から, 狩編業務 や特定鳥獣保護管理計画における計画策定の一部も担当 していた。被害防除だけでなく個体数管理に関する業務 の一部まで担い，6府県の中でも特に農業部局の役割が 大きかった（図 2)。

滋賀県 環境部局と農業部局が業務を分担していた。 2009 年度より和歌山県と同じく，農業部局に獣害対策専 門の「農業経営課 水田農業・獣害対策担当」が設置され た（図 1)。ただし，所掌業務は特措法の所管と被害防除 に関わるものだけであり，和歌山県に比べると農業部局 の役割は小さかった（図 2)。

奈良県 林務部局と農業部局が業務を担当し，林務部局 が鳥獣保護法による計画策定，狩猟業務を，農業部局が 特措法の所管と被害防除に関わる業務を所掌していた （図 2)。また，2006 年度より農林水産部に「鳥獣害対策 本部」が設置され，林務部局と農業部局の連携体制が構 筑されていた。 


\begin{tabular}{|c|c|c|c|c|c|}
\hline \multirow{2}{*}{\multicolumn{2}{|c|}{ 兵庫県 環境部局が鳥獣保護 }} & 涺 & & & \multirow{5}{*}{ その他 } \\
\hline & & 環境生活部 & \multicolumn{2}{|c|}{ 農林水㿷部 } & \\
\hline 法における計画策定，狩悦業 & 和歌山 & 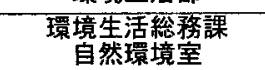 & & \\
\hline 務，特措法所官を担当し，辰 & \multirow[b]{2}{*}{ 滋賀 } & 琵琶湖㯖境部 & 農政水産部 & & \\
\hline 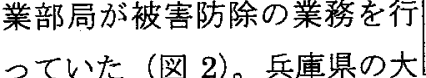 & & $\begin{array}{l}\text { 自然環境保全課 } \\
\text { 野生動物担当 }\end{array}$ & 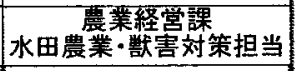 & & \\
\hline 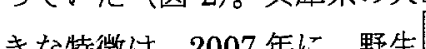 & \multirow[b]{2}{*}{ 兵庫 } & \multicolumn{4}{|c|}{ 農政環境部 } \\
\hline 動物専門の研究機関として & & 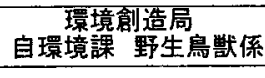 & 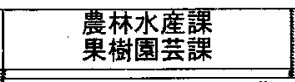 & & 森林動物研究センター \\
\hline 「森林動物研究センター」が & \multirow{2}{*}{ 奈良 } & & \multicolumn{2}{|c|}{ 䔩柯遠会誅 } & \\
\hline 設置された点である。これに & & & 農業水産掁藇課 & $\begin{array}{l}\text { 森㷊整備課 } \\
\text { 鳥謤護 } \\
\end{array}$ & \\
\hline より, 野生動物の生態の研究 & \multirow{2}{*}{ 京都 } & & \multicolumn{2}{|c|}{ 農林水産部 } & \\
\hline や獣害対策の技術開発が強力 & & & & 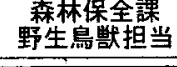 & \\
\hline に進められていた。(図 1)。 & \multirow{2}{*}{ 大阪 } & & \multicolumn{3}{|c|}{ 農政環境部 } \\
\hline 大阪府 林務部局より派生し & & & 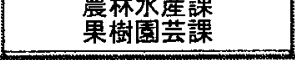 & & 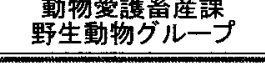 \\
\hline
\end{tabular}

た，野生動物に関係する部局 が鳥獣保護法における計画策

図 1 各府県における被害対策体制

定，狩猟業務，特措法所管を，農業部局が被害防除に関わ る業務を担当する分担関係にあった（図 2 )。

京都府 林務部局が，鳥獣保護法の所管とそれに伴う計画 策定，狩猟，特措法の所管，被害防除に関する全業務を所 掌し（図 2)，農業部局は獣害対策に関して具体的な業務を 持たない体制が長く取られてきた。2011 年度からは，農 林水産部に「野生鳥獣等被害対策推進本部」が設置され, 被害対策への農業部局の参加が図られていた。

（2）部局とその特徴

環境部局，農業部局，林務部局の被害対策業務における 役割と市町村や地元住民との関係に関して，以下のような 特徽が明らかになった。なおこれらは，6府県の担当部局 を俯瞰することで得られた全般的な特徴であり，一部では 状況が異なる場合もある。

農業部局 県民局 (兵庫県) や振興局 (和歌山県) 等の出 先機関を持ち，普及指導員等を通じて市町村や地元住民と の密な連絡体制を築いていた。農業者に近い立場で業務を 行える点が特徵だが, 捕獲権限等が集中すると, 例えば「農 業者からの捕獲の強い要望がある」ため,「被害軽減を重 視するあまり過剩な捕獲を行う危険性」(いずれも和歌山 県農業部局）を懸念していた。

環境部局 野生動物保護の観点からの保護管理の計画作 成により，過剩な捕獲等，行き過ぎた被害对策の抑制を担 っていた。しかし，農業部局のような出先機関を持たず， 被害の発生地域の住民とのつながりは薄かった。

林務部局 農業部局と同样，出先機関を通じて市町村との 関係を持っていた。ただし，農業部局ほど農業被害の発生 する地域の住民と密な関係は持たなかった。

\section{（3）獸害対策体制の形態}

以上の結果をもとに 6 府県における獣害対策の体制を， 被害防除と個体数管理に関わる業務を担当する部局によ

\begin{tabular}{|c|c|c|c|c|}
\hline & 計画策定 & 狩編業務 & 特措法 & 被害防除 \\
\hline 和歌山 & 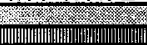 & 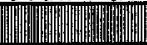 & 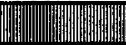 & \\
\hline 滋賀 & 3 & $2 \times 2=$ & 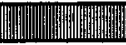 & 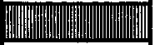 \\
\hline 兵庫 & 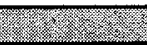 & 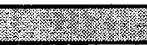 & 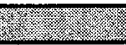 & 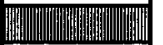 \\
\hline 奈良 & & & 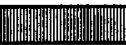 & 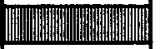 \\
\hline 京都 & & & & \\
\hline 太阪 & & & & 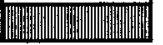 \\
\hline
\end{tabular}

図 2 各府県における各部局の担当業務 Fig.2 Roles of each Division in each Prefecture.

って3つの形態に分類した。

(1)被害防除と個体数管理を異なる部局が分担する府県

（滋賀，兵庫，奈良，大阪）

滋賀県, 兵庫県, 奈良県, 大阪府では, 個体数管理を 行う部局と被害防除を行う部局が異なっていた。農業部 局が被害防除の業務を担う一方，環境部局や林務部局な どが個体数管理の業務を行っていた注2)。「保護の視点か ら捕獲に歯止めをかけられる」(滋賀県環境部局)といら ように，2つの部局が業務を分担することで獣害対策と 野生動物保護のバランスが保たれていた。

(2)被害防除と個体数管理を農業部局が専管する府県（和 歌山県)

和歌山県は狩猟業務や計画策定の一部，被害防除に至 るまで農業部局が業務に関わっており，被害防除，個体 数管理の両面を担当する農業部局の役割が大きかった。 被害防除と個体数調整を同時に計画することが可能であ るが，捕獲権限等が農業系課に集中すると，地元の要望 により捕獲が過剩となる危険性がある。

(3)被害防除と個体数管理を農業部局以外の部局が尃管す る府県（京都府）

京都府では，個体数管理に関わる業務と被害防除に関 わる業務の両方を林務部局が尃管しており, 獣害対策 
表 1 対象市町村と府県の体制

Table 1 Municipalities and Implementation System of Wildlife Management in Prefectures.

\begin{tabular}{c|l|l|l|l}
\hline 形態 & 市町村 & \multicolumn{1}{|}{ 市町村の部局 } & 府県 & \multicolumn{1}{|c|}{ 府県の獣害対策体制 } \\
\hline (1) & 甲賀市 & 産業経済部鳥獣害対策室 & 滋賀県 & 被害防除と個体数管理を異なった部局が分担 \\
\hline (2) & 紀美野町 & 産業課 & 和歌山県 & 被害防除と個体数管理を農業部局が担当 \\
\hline (3) & 南丹市 & 農林商工部農林整備課 & 京都府 & 被害防除と個体数管理を農業部局以外の部局が担当 \\
\hline
\end{tabular}

について農業部局は具体的な業務を持たなかった。ただ

し，獣害対策に関する普及・指導は農業部局管轄である 地域農業改良普及センターの職員が担当していた。さら に「野生鳥獣等被害対策推進本部」が設置され，業務一 の農業部局の参加が図られているが，依然として林務部 局を中心とした体制であるため，「被害対策における出 先機関を通じた地元とのつながりが他の府県に比べて 弱い」(京都府林務部局) と評価されていた。

\section{2 市町村との関係}

以上の類型区分をもとに，それぞれ滋賀県甲賀市（類型 (1)）, 和歌山県紀美野町 (類型(2)), 京都府南丹市 (類型(3) の担当者へ行ったヒアリング調查より，府県と市町の関係 と府県の形態による関係性の違いを整理した。

（1）府県の形態による市町村との関係の違い

(1)被害防除と個体数管理を異なる部局が分担する府県 (滋 賀県 甲賀市)

甲賀市の担当者は，「県の環境部局が被害防除に関する 事項，農業部局が個体数調整に関する事項について十分に 知らないと感じることがある」，「環境部局と農業部局，両 部局のスケジュールの調整が難しいり，「住民に対策につい て説明する際には被害防除と個体数管理の両面の話がで きないと理解が得られないが, どちらかの部局だけではそ れができない」など，県内の部局間の調整に不十分な部分 がある点を問題点として指摘した。

(2)被害防除と個体数管理を農業部局が専管する府県 (和歌 山県 紀美野町)

紀美野町の担当者は, 町にとっての県の空口は農業部局 がほとんどであり，県と町の業務の調整は「空ロがひとつ で行いやすいと評価していた。県の実施体制について特 段の不満は聞かれなかった。

(3)被害防除と個体数管理を農業部局以外の部局が専管す る府県 (京都府 南丹市)

南丹市の担当者は，「府におうける担当部局がひとつであ るほうが府との調整を行いやすい」と答えた。ただし，府 や出先機関との連絡調整体制の問題として「出先機関の担 当者は市と密接に関わり；意思疎通が図れているが，本庁 には市の意見が伝わりにくいことがある」，「市と府の板ば さみになる出先機関は大変」と答えた。このように，農業 部局所管の出先機関である南丹農業改良普及センターの 職員の役割を高く評価する一方で，本庁において中心的な
役割を担う林務部局との意思疎通や調整には不満の声が 聞かれ，府の本庁と出先機関の連携における課題がうか がえた。

(2) 府県と市町村との関倸

(1)被害防止計画と特定鳥獣保護管理計画との調整

ニホンジカ，イノシシは 3 市町すべてで，またニホン ザルは滋賀県甲賀市, 京都府南丹市で被害防止計画対象 となっていた。いずれの場合も, 被害防止計画の作成に あたり，府県担当者との協議を通じて，保護事業計画お よび保護管理計画との整合性が保たれていた。

3 市町では，被害防止計画のイノシシ，ニホンジカの 捕獲計画数は，市町村における直近の捕獲数の実績をも とに立てられていだ)、4)、5)。ヒアリングでは，イノシ シ, ニホンジカの被害対策について，狩猟者の減少や高 齢化など，捕獲の実施能力に限界が指摘された。これに ついて甲賀市の担当者は，「二ホンジカを捕れるだけ捕っ ても, 県の特定鳥獣保護管理計画で目標とされる個体群 密度まで減少しない」と述べていた。

ニホンザルについて例えば南丹市の担当者が「地元は 全頭捕獲してほしいと言っている」というように被害発 生地の住民からの捕獾の要望が大きかった。しかし, 滋 賀県, 京都府の特定計画では個体群保護の観点から, 二 ホンザルの有害鳥獣駆除の上限を群れの個体数の $10 \%$ と 定めており6)，71，滋賀県甲賀市，京都府南丹市の被害防 止計画における捕獲計画はこの制限に従っていた 注3)。市町の被害防止計画作成においては府県との調整が 十分に行われているといえる。

(2)市町村における獣害対策実施の現状

財政支援 府県や市町担当者へのヒアリングでは，「県で も市町村でも予算が願しい」,「どの市町でも事業の申請 が多くなってきた」（和歌山県 紀美野町）のように，対 策害施するための予算の不足が指摘された。市町村の多 くは被害対策の財源として，農林水産省所管の鳥獣害防 止総合対策事業に大きく依存していた。とりわけ被害防 止計画を策定した市町村については，農林水産省の鳥獣 害防止総合対策事業と特別交付税措置により, 侵入防止 柵の設置などのハード事業の顀担が 1 割となる措置が取 られており ${ }^{8)}$, これが, 被害防止計画の作成のインセン ティブとなっていた。また事業そのものについても，「府 県による補助金の上乗せ義務がないので，府県にとって も利点だと思う」（京都府 南丹市）や「県から農林水産 
省の事業の導入を提案された」（和歌山県 紀美野町）等， 府県の財政支援が限界に達する一方，国の財政支援への領 域の拡大が確認できた。

担当人員 滋賀県甲賀市では平成 23 年度より，獣害対策 に関する業務の專門部署として，産業経済部に鳥獣害対策 室が設置された。しかし，「市町村では農林部局の職員が 業務を行っていることがほとんど」(京都府林務部局)で あり，専門職員が配置されている市町村は少数に過ぎない。 多くの市町村は南丹市や紀美野町のように，農林業部局の 職員が他の業務と兼務しているのが現状である。これら 2 市町では，獣害対策に関わる業務に 2 人が携わっていたが， 獣害対策に関わる業務に十分に労力をかけることができ ないとの声が聞かれた。

\section{$\mathrm{V}$ 考察}

\section{1 府県における部局間連携の重要性と課題}

近畿 6 府県では，京都府を除き複数の部局が業務を分担 する体制が敷かれていた。農業被害の拡大が進む中で，被 害発生地である農業地域の住民と出先機関を通じてつなが りを持つ農業部局の役割はより重要なものとなっており， 和歌山県や滋賀県のように近年，農業部局に獣害対策専門 の担当を設置したり，狩猟管理の権限を委譲したりするな ぞ，農業部局の権限が拡大される例もある。

都道府県は，農作物被害の軽減だけでなく，野生動物の 保護も進めなければならない。その意味では，環境部局の 様な鳥獣保護法を所管する部局が，被害対策に関わり，業 務を分担することは効果的と考えられる。

ただし，府県で業務が複数の部局に分担されている場合， 部局間の調整不足や担当者の知識不足が，市町の担当者の 立場から問題として指摘される事例もあった。これは，(1) 都道府県における対策業務に関わる部局が，他の部局の業 務内容を十分に把握できていないことや，(2)部局間の調整 が不十分なままに，それぞれの部局が市町に個別に対応し ていることが原因と考えられる。

このように，立場の異なる部局による業務の分担は重要 であるが，その結果，調整や知識共有の不足が生じること もある。こうした問題を解決するためには，府県において， 複数部局の業務の詳細を把握できる立場の職員を配置した り，奈良県や京都府で行われているような「対策本部」の 設置など，複数部局間の知識や情報の共有体制を強化する 必要がある。

\section{2 獣害対策における府県と市町村の役割}

特措法により市町村の権限が搪大したことや，農林水産 省の鳥獣害防止総合対策事業の後押しを受け，鳥獣保護法 を所管する都道府県との棲み分けが徐々に進みつつある。
これは，「県は個体数管理等の計画をしっかり行い，被害 防除は市町村に頑張ってもらう」（滋賀県環境部局）とい う意見にも表れている。今後も, 獣害対策，特に被害防除 における市町村の役割は重要となるだろう。他方, 府県に は，市町村の対策を後押しする，正確なデータに基づく保 護事業計画や特定計画の策定の役割がこれまで以上に求 められるだろう。

\section{3 獣害対策における府県と市町村の対処能力}

府県へのヒアリングで客観的な科学的データが不足し ている」（和歌山県農業部局）といった意見が聞かれたよ うに，府県が持つ野生動物の生息状況の把握や被害対策に 資する正確な調查を行うための体制は十分とは言えない。 また，野生動物の行動域は都道府県境をこえて広範囲にわ たるため,複数の都道府県による広域での連携も必要とな る ${ }^{9}$ 。近畿地方では近畿地域野生鳥獣対策連絡協議会が設 置されている。また，南丹市では平成 22 年度より，京都 府，大阪府，兵庫県の計 13 市町で南丹・北摄地域鳥獣被 害防止対策連絡協議会住4) が設置されるなど，複数府県間 の情報共有の体制も存在する。しかし，「調查の方法も府 県によって異なる」（京都府林務部局）ため，データの共 有と調查手法の統一もままならない状況である。こうした 課題に対処する上で, 例えば兵庫県の森林動物研究センタ 一のような専門の研究機関の設置も有効上考えられる。た だし,都道府県においても財源が不足しているのが現状で あり，被害防除だけではなく、このような基整的な情報の 収集に対しても調查分析手法の指針提示や財政支援など， 国の支援が求められる。

特措法の制定や鳥獣害防止総合対策事業の拡充により， 市町村の権限が拡大し, 財政負担が軽減されたが，獣害 対策に関わる職員の数は十分とはいえない。また一部獣 種では，捕獲数も府県の計画の目標数に達しないなど， 捕獲の実施人員の不足も顕在化している。さらに市町村 合併による旧市町村間での調整の課題も考えられる。こ のような課題は本研究で対象とした以外の多くの市町村 においても同様に存在すると推測でき，権限が应大され ても，実際には多くの市町村で積極的な取組みが害行で きないのが現状だと考えられる。

\section{VI おわりに}

本研究では，近畿地方に扔ける獣害対策を事例に，部 局間の関係，市町村との関係を中心に府県における被害 対策体制の特徽と課題について検討した。

近年の法整備よって，対策の実施主体が市町村人と移 行した。獣害対策の中で都道府県に求められる機能は、 正確なデータの収集とそれに基づく個体数管理等の計画 
策定、市町村に対する技術的・財政的支援など、市町村の 取り組みを補完するものに移りつつある。これらの機能を 発揮するために、単一部局による体制がとられる府県では、 市町村、被害発生地の住民など樣々な他主体との連絡調整 を図るため、例えば他部局の出先機関であっても綿密なや り取りが行えるような体制づくりが必要である。一方複数 部局による連携が取られる府県では、他主体との連絡調整 をより効率的に行うために、対策本部の設置などの各部局 間のさらなる連携、情報共有が重要である。さらにはデ一 タ収集方法の統一や広域での個体数管理など、府具間の連 携も今後さらに進めなければならない。

なお, 本研究の結果は近畿 6 府県を対象に実施した調查 による府県の対応体制の類型化と, 各類型に属する市町村 ヒアリングに基づくものである。全国を俯瞰すれば，本研 究で整理したものとは異なる体制を持つ都道府県も存在 するも考えられる。また，市町村ヒアリングは，各類型で 1 つしか実施できていない。今後は，近畿府県の市町村担 当者を対象としたアンケート調查により，本研究で得られ た知見の一般性を確認する必要がある。また，他都県につ いても，本研究と同様の調查を実施することで，知見の一 般性を確認する予定である。

\section{注}

注 1)「市町村長は…都道府県知事に対し，必要な措置を講 ずるよう要請することができる」(第 7 条)，「国及び 地方公共団体は，‥捕獲等一の貢献に対する報償金 ‥の必要な措置を講ずるよう努めるものとする」(第 16 条) など，市町村の権限や，国・都道府県の財政 支援の拡充が図られている。

注 2) 特措法の所管が滋賀県, 奈良県では農業部局にあり, 兵庫県, 大阪府では農業部局以外の部局にあったが,
ヒアリングの結果, 特措法の所管については施策の 実施等には関係がなかったため，本研究では同一の 形態として分類した。

注 3）和歌山県では 2004 年まで策定されていたニホンザ ルとタイワンザルの交雑個体群を対象とした特定 計画のデータをもとにニホンザル被害のある市町 村の捕獲計画との調整が行われている。

注 4）広域協議会設置により，鳥獣被害防止総合対策交付 金による財政支援を受けることができる。

\section{引用文献}

1）赤坂猛: 鳥獣保護法と国, 都道府県及び市町村, ワ イルドライフ・フォーラム, 16(1), pp20-23.

2）農林水産省生産局（2006）:『野生鳥獣被害止マニュ アルー生態と被害防止対策（基礎編）一』

3）紀美野町（2010）:『紀美野町鳥獣被害防止計画』

4）甲賀市・湖南市（2011）:『甲賀地域鳥獣被害防止計 画』

5）南丹市（2011）:『南丹市鳥獣被害防止計画』

6）滋賀県（2012）:『滋賀県ニホンザル特定鳥獣保護管 理計画 (第 3 次)』

7) 京都府（2012）:『特定鳥獣保護管理計画一ニホンザ ルー (第 2 期)』

8）農林水産省: 鳥獣害防止総合対策事業パンフレット,く http://www.maff.go.jp/j/seisan/tyozyu/higai/pdf/h20pan ph.pdf〉, 2012 年 12 月, 2012 年 5 月 8 日.

9) 農林水産省:鳥獣による農林水産業等に係る被害の防 止のための施策を実施するための基本的な指針，〈http:// www.maff.go.jp/j/seisan/tyozyu/higai/h_horitu/sisin/pdf kihon.pdf〉，2008 年 2 月，2012 年 5 月 8 日.

Summary : This study focuses on implementation system of wildlife management in six prefectures of Kinki region from the view point of governmental organizational structures. The roles and relationships of relevant departments and their subsidiary bodies were clarified through interview surveys to prefectural officials, which were then classified into three types. The performances and problems of the three types of implementation system of wildlife management were identified by the interview to municipal officials in charge of wildlife management. We identified that 1) three implementation systems showed different performances and problems in their operation and cooperation with municipalities, 2) cooperation among relevant departments and their subsidiary bodies with different authorities are of crucial importance to deal with wildlife management and also to provide support for municipalities and 3) liaison and adjustment between prefectures and municipalities are important for effective wildlife management. .

キーワード (Keywords): 獣害 (Agricultural damage by wildlife), 対策実施体制 (Implementation system of wildlife management), 都道府県（Prefectures），市町村（Municipalities） 